\title{
GAMBARAN PERILAKU MASYARAKAT DALAM MEMBUANG SAMPAH RUMAH TANGGA DI WILAYAH PESISIR RT 03 / RW 01 KELURAHAN KASTURIAN KECAMATAN TERNATE UTARA TAHUN 2015
}

\author{
Dwi Wahyu Purwiningsih ${ }^{1}$, Damitha Adriyanti Ishak ${ }^{2}$ \\ Jurusan Kesehatan Lingkungan Poltekkes Kemenkes Ternate
}

\begin{abstract}
Abstrak
Sampah merupakan salah satu peluang pencemaran lingkungan disertai penurunan kualitas estetika. Jumlah penduduk juga dapat mempengaruhi peningkatan jumlah sampah. Selain itu, perilaku masyarakat membuang sampah di pesisir pantai terutama juga merupakan salah satu kebiasaan yang dapat menimbulkan dampak negatif. Tujuan dari penelitian ini adalah untuk memperoleh gambaran perilaku masyarakat dalam membuang sampah rumah tangga pada wilayah pesisir Kelurahan Kasturian RW 01 / RT 03 Kecamatan Kota Ternate Utara tahun 2015. Penelitian ini merupakan penelitian deskriptif dengan besar responden sebanyak 38 orang. Hasil penelitian ini adalah Masyarakat mempunyai pengetahuan baik tentang perilaku membuang sampah diwilayah pesisir sebanyak 13 responden $(34.2 \%)$ dan pada kategori sedang sebanyak 21 responden $(55.3 \%)$ dan pada kategori kurang sebanyak 4 responden ( 10.5\%). Masyarakat memiliki sikap positif sebanyak 30 responden $(79.1 \%)$, dan pada sikap negative sebanyak $8(21 \%)$. Karena kebanyakan dari mereka lebih menyatakan sangat setujunya terhadap pertanyaan yang diberikan peneliti. Dalam ketersediaan sarana TPS masyarakat banyak yang tidak memiliki dan berperilaku buruk dalam membuang sampah rumah tangga diwilayah pesisir sebesar 22 responden (57.9\%).
\end{abstract}

Kata kunci : Perilaku Masyarakat, Sampah, Wilayah Pesisir

\section{PENDAHULUAN}

Sampah selalu timbul menjadi persoalan rumit dalam masyarakat yang kurang memiliki kepekaan terhadap lingkungan. Ketidak disiplinan mengenai kebersihan dapat menciptakan suasana semrawut akibat timbunan sampah. Begitu banyak kondisi tidak menyenangkan akan muncul. Bau tidak sedap, lalat berterbangan, dan gangguan berbagai penyakit siap menghadang di depan mata. Tidak cuma itu, peluang pencemaran lingkungan disertai penurunan kualitas estetika pun akan menjadi santapan seharihari bagi masyarakat ( Sugito, 2008).

Peningkatan jumlah produksi sampah tentunya akan memberikan efek pada kesehatan lingkungan yang di dalamnya terdiri dari adanya masyarakat maupun mahluk hidup lainnya. Masalah ini akan muncul ketika sampah tidak dapat di tanggani dengan baik oleh pemerintah setempat penyediaan TPS yang masih minim di kawasan pesisir akan menimbulkan pembuangan sampah yang secara sembarangan. Masyarakat akan lebih condong membuang sampah di laut dan ini akan berefek pada pencemaran laut dan tentunnya menggangu ekosistem laut serta kesehatan masyarakat.

Kota ternate merupakan kota pulau dengan dinamika perkembangan kota berlangsung di sepanjang pesisir. Pertumbuhan penduduk yang cukup tinggi maka kebutuhan akan ruang semakin meningkat. Kondisi topografi kota Ternate yang tidak rata menjadikan wilayah pesisir menjadi pilihan utama. masalah satu bentuk pemanfaatn ruang pesisisr adalah sebagai fungsi permukiman. Perkembangan permukiman ini tidak di sertai dengan memadainya prasarana dasar permukiman, akibatnya sampah yang berasal dari aktivitas penduduk setempat di buang di sekitar pantai yang dapat mencemari wilayah pesisir. Kota Ternate 
juga salah satu daerah yang ada di Indonesia yang masih memiliki beberapa kawasan yang masuk pada pemukiman kumuh. Untuk kota Ternate sendiri beberapa tempat atau kelurahan yang kondisinya pemukimannya sangat memprihatinkan khususnya pemukiman yang berada di kawasan pesisir yakni antara lain kelurahan Salero, kelurahan Kasturian, kelurahan Makkasar Timur, kelurahan Mangga dua, kelurahan Bastiong dan kelurahan lainnya.

Kelurahan Kasturian termasuk dalam wilayah kecamatan Ternate utara, dengan luas wilayah secara keseluruhan 20.000 Ha. Terdapat 9 RT dan 4 RW yang memiliki jumlah penduduk sebesar 3278 jiwa yang terdiri dari $2561 \mathrm{KK}$ dengan jumlah jiwa perempuan sebesar 1626 jiwa dan laki-laki sebesar 1652 jiwa. Secara fisik kelurahan kastruyan terdiri atas wilayah permukiman di daratan dan di atas laut atau biasa disebut dengan rumah panggung (Data Sekunder Kelurahan Tahun 2015).

Sebagian besar masyarakat di RT 03/RW 01 Kelurahan Kasturian Kota Ternate pada bagian pesisir ini mempunyai kebiasaan membuang sampah di pinggiran pantai yang ada di Kelurahan tersebut. dari kebiasaan inilah menimbulkan dampak dari sampah yang belum terbawa arus air tersebut. sehingga menimbulkan berbagai masalah. Lingkungan di sekitar tepi pantai terlihat sangat kotor akibat tumpukan sampah, lalat beterbangan, banyak tikus dan nyamuk, bahkan menyebarkan aroma yang tidak sedap yang masyarakat hirup. (PBL Pemukiman tahun 2014)

Berdasarkan uraian di atas, peneliti tertarik untuk melakukan penelitian dengan judul Gambaran Perilaku Masyarakat Dalam Membuang Sampah Rumah Tangga Di Wilayah Pesisir Rt 03 / Rw 01 Kelurahan Kasturian Kecamatan Ternate Utara Tahun 2015

\section{METODE}

Penelitian ini adalah merupakan penelitian dengan metode deskriptif yaitu jenis penelitian yang bersifat memberikan gambaran perilaku masyarakat dalam membuang sampah rumah tangga pada daerah pesisisir kelurahan kasturian RT 03 I RW 01 Kota Ternate (Notoatmodjo, 2012). Dalam mengukur aspek perilaku ada 2 jenis variable yaitu : Pengetahuan dan sikap. Menurut Pratomo (2009) memberikan gambaran untuk mengklafikasikan dengan perhitungan sebagai berikut :

Tingkat pengetahuan dan sikap baik jika total skor $>78 \%$

Tingkat pengetahuan dan sikap sedang jika total skor $40 \%-78 \%$

Tingkat pengetahuan dan sikap kurang jika total skor $<40 \%$

Populasi pada penelitian ini adalah masyarakat Kelurahan Kasturian Kecamatan Kota Ternate Utara khususnya RT 03 / RW 01 dengan jumlah penduduk sebesar 441 jiwa dengan jumlah KK sebesa 97 KK. Sampel dalam penelitian ini adalah masyarakat Kelurahan Kasturian RT 03 / RW 01 Kota Ternate Khususnya pada wilayah daerah pesisir dengan jumlah KK sebesar 38 KK. Pengambilan sampel dalam penelitian ini dilakukan secara total sampling dimana sampel diambil secara keseluruhan pada satu lokasi RT 03 / RW 01 Kelurahan Kasturian khususnya pada wilayah pesisir.

\section{HASIL}

Sesuai dengan yang tujuan yang ingin dicapai, maka peneliti melakukan wawancara dan pengamatan dengan menggunakan lembar kuesioner dan observasi. Data yang diperoleh dalam bentuk tabel dan grafik kemudian dianalisis sehingga dapat diketahui bagaimana tingkat pengetahuan,sikap dan ketersediaan sarana masyarakat dalam membuang sampah rumah tangga di wilayah pesisir RT 03 / 01 yang berada di wilayah pesisir Kelurahan Kasturian Kecamatan Ternate Utar Tahun 2015. 
Pada aspek pengetahuan responden yang mengetahui pengertian dari sampah sebanyak 35 responden $(92.1 \%)$ dan yang tidak mengetahui pengertian dari sampah sebanyak 3 responden (7.9\%). Pengetahuan responden yang mengetahui perbedaan antara sampah organik dan anorganik sebanyak 35 responden $(92.1 \%)$ dan yang tidak mengetahui peerbedaan sampah organik dan anorganik sebanyak 3 responden (7.9\%). Pengetahuan responden yang mengetahui adanya manfaat jika membuang sampah di TPS sebanyak 33 responden $(86.8 \%)$ dan yang tidak mengetahui adanya manfaat jika membuang sampah di TPS sebanyak 5 responden $(13.2 \%)$.

Pengetahuan responden sampah yang di buang di pisahkan sebanyak 15 responden $(39.5 \%)$ dan yang tidak memisahkan sampah sebelum dibuang sebanyak 23 responden $(60.5 \%)$. pengetahuan responden Tentang adanya akibat bila membuang sampah di laut sebanyak 35 responden (92.1\%) dan yang tidak mengetahui adanya akibat bila membuang sampah di laut sebanyak 3 responden $(7.9 \%)$.

Pengetahuan responden Tentang membuang sampah di laut dapat menyebabkan penyakit sebanyak 34 responden (89.5\%) dan yang tidak mengetahui apabila membuang sampah di laut dapat menyebabkan penyakit sebanyak 4 responden (10.5\%). pengetahuan responden Tentang adanya dampak negative bila membuang sampah di laut sebanyak 37 responden (97.4\%) dan yang tidak mengetahui adanya dampak negative bila membang sampah di laut sebanyak 1 responden $(2.6 \%)$.

Pengetahuan responden Tentang terjadinya penumpukan sampah di laut menyebabkan tempat perkembangbiakan vektor sebanyak 35 responden $(92.1 \%)$ dan yang tidak mengetahui terjadinya penumpukan sampah di laut menyebabkan tempat perkembangbiakan vektor sebanyak 3 responden (7.9\%). pengetahuan responden tentang membuang sampah di laut merusak estetika laut sebanyak 37 responden (97.4\%) dan yang tidak mengetahui akibat membuang sampah di laut merusak estetika laut sebanyak 1 responden (2.6\%). Pengetahuan responden tentang membuang sampah diwilayah pesisir kategori baik di kelurahan kasturian sebanyak 13 responden (34.2\%), kategori sedang sebanyak 21 responden $(55.3 \%)$ dan kurang sebanyak 4 responden $(10,5 \%)$.

Sikap responden terhadap pernyataan diatas untuk setiap rumah tangga memiliki TPS ( tempat pembuangan sampah) yang terbanyak adalah sangat setuju sebanyak 30 responden $(78.9 \%)$, sedangkan yang tidak setuju yaitu 0\%. sikap responden terhadap pernyataan di atas dalam setiap rumah tangga sampah yang dimiliki di lakukan pemisahan antara yang mudah membusuk dan tidak mudah membusuk yang terbanyak adalah sangat setuju sebanyak 32 responden $(84.2 \%)$, sedangkan yang tidak setuju yaitu $0 \%$.

Sikap responden terhadap pernyataan di atas untuk setiap rumah tangga dilakukan pemisahan yang terbanyak adalah sangat setuju sebanyak 26 responden (68.4\%), sedangkan yang tidak setuju yaitu $0 \%$. sikap responden terhadap pernyataan di atas untuk sampah yang dihasilkan dikurangi jumlahnya untuk mengurangi dampak negatif yang terbanyak adalah sangat setuju sebanyak 38 responden $(100 \%)$ sedangkan yang tidak setuju yaitu 0\%. sikap responden terhadap pernyataan di atas untuk barangbarang yang dapat digunakan untuk mengurangi produksi sampah yang terbanyak adalah sangat setuju sebanyak 23 responden $(60.5 \%)$, sedangkan yang tidak setuju yaitu 0\%. sikap responden terhadap pernyataan di atas untuk sampah dimanfaatkan kembali sehingga bernilai positif yang terbanyak adalah sangat setuju sebanyak 27 responden (71.1\%), sedangkan yang tidak setuju yaitu $0 \%$.

Sikap responden terhadap pernyataan di atas untuk sampah tidak dibuang tapi dimanfaatkan kembali yang terbanyak 
adalah sangat setuju sebanyak 38 responden $(100 \%)$, sedangkan yang tidak setuju yaitu $0 \%$. sikap responden terhadap pernyataan di atas untuk meminimalisasi terjadinya banjir, dibuat lubang resapan untuk meningkatkan daya resap air yang terbanyak adalah setuju sebanyak 28 responden $(73.7 \%)$, sedangkan yang tidak setuju yaitu $0 \%$.

Sikap responden terhadap pernyataan di atas untuk mengatasi sampah organic, dilakukan pengomposan dalam lubang resapan biopori yang terbanyak adalah setuju sebanyak 25 responden $(65.8 \%)$, sedangkan yang tidak setuju yaitu $0 \%$. sikap responden terhadap pernyataan di atas untuk lubang resapan dibuat dihalaman rumah atau pekarangan rumah perbanyak adalah sangat setuju sebanyak 20 responden (47.4\%), sedangkan yang tidak setuju yaitu 0\%. sikap responden tentang membuang sampah diwilayah pesisir kategori baik di kelurahan kasturian sebanyak 30 responden $(79.0 \%)$, kategori sedang sebanyak 8 responden $(21.0 \%)$.

\section{PEMBAHASAN}

Pengetahuan merupakan hasil dari tahu dan ini terjadi setelah orang melakukan penginderaan terhadap suatu obyek tertentu. Pengetahuan merupakan domain yang sangat penting dalam membentuk tindakan seseorang (Overt bahvior). Semakin banyak ragam sumber informasi atau penyuluhan yang diperoleh seseorang maka semakin baik pengetahuan orang tersebut (Saifuddin Azwar, 2005). Dengan demikian untuk meningkatkan pengetahuan responden dalam membuang sampah rumah tangga di wilayah pesisir perlu di adakan penyuluhan kepada masyarakat yang berada di wilayah pesisir.

Sikap adalah aksi atau respon yang masih tertutup terhadap suatu stimulas atau obyek. Sikap juga merupakan organisasi pendapat, keyakinan seseorang mengenai obyek atau situasi yang relative. Yang di sertai adanya perasaan tertentu dan memberikan dasar kepada orang tersebut untuk membuat respon atau berperilaku dalam cara tertentu yang di pilihnya. Jadi dapat di simpulkan bahwa sikap dapat berupa respon negative dan respon positif yang akan mencerminkan dalam bentuk perilaku. Sikap responden tentang membuangan sampah di wilayah pesisir adalah sejauh mana responden bersikap Negatif dan Positif dalam memberikan tanggapan atas pertanyaan yang diberikan. Berdasarkan hasil wawancara dengan responden dapat diketahui bahwa sebagian besar responden memiliki sifat positif, yaitu kebanyakan dari mereka menyatakan sangat setuju jika membuang sampah agar dipisahkan, sampah dimanfaatkan kembali agar bernilai bagi masyarakat. Di samping itu sikap positif responden dipengaruhi oleh beberapa fakor yaitu tingginya tingkat pendidikan sehingga mendorong seseorang berpikiran positif terhadap apa yang mereka ketahui.

Penelitian yang dilakukan oleh Maritsa Rahman Ashidiqy (2009) tentang faktor-faktor yang berhubungan dengan perilaku masyarakat dalam membuang sampah rumah tangga di sungai Mranggen di kota semarang mengatakan bahwa 45 responden $(100 \%)$ yang bersifat negatif, terdapat 41 responden $(85,4 \%)$ membuang sampah rumah tangga di sungai, dan sebanyak 4 responden $(21.1 \%)$ tidak membuang sampah rumah tangga di sungai. Sedangkan dari 22 responden $(100 \%)$ yang bersikap posotif, terdapat 7 responden $(14,6 \%)$ membuang sampah rumah tangga di sungai dan 15 responden (78.9\%) tidak membuang sampah rumah tangga di sungai. Dengan hasil uji Chi Square, diperoleh $\mathrm{p}$ Value 0,0001 dengan $\alpha C C$ sebesar 0,526 sehingga dapat diketahui bahwa ada hubungan antara pengetahuan responden dengan perilaku membuang sampah rumah tangga disungai dengan tingkat keeratan hubungan kategori sedang.

\section{KESIMPULAN DAN SARAN}

Berdasarkan hasil dan pembahasan dapat di simpulkan : Masyarakat mempunyai pengetahuan baik tentang 
perilaku membuang sampah diwilayah pesisir sebanyak 13 responden $(34.2 \%)$ dan pada kategori sedang sebanyak 21 responden $(55.3 \%)$ dan pada kategori kurang sebanyak 4 responden ( $10.5 \%)$. Masyarakat memiliki sikap positif sebanyak 30 responden $(79.1 \%)$, dan pada sikap negative sebanyak $8(21 \%)$. Karena kebanyakan dari mereka lebih menyatakan sangat setujunya terhadap pertanyaan yang diberikan peneliti. Dalam ketersediaan sarana TPS masyarakat banyak yang tidak memiliki dan berperilaku buruk dalam membuang sampah rumah tangga diwilayah pesisir sebesar 22 responden $(57.9 \%)$.

Saran adanya penelitian lebih lanjut meneliti faktor-faktor yang berhubungan dengan perilaku masyarakat dalam membuang sampah rumah tangga diwilayah pesisir

\section{DAFTAR PUSTAKA}

Ashidiqy, Marista Rahman. 2009. Skripsi."Analisis Faktor-Faktor Yang Berhubungan Dengan Perilaku Masyarakat Dalam Membuang Sampah Rumah Tangga Di Sungai Mranggen. Universitas Negeri Semarang. Semarang.

Chandra Budiman. 2012 "Pengantar Kesehatan Lingkungan". Jakarta. EGC.

Data Demografi Kelurahan Kasturyan Kec.Ternate Utara. 2015.

Djafar Irene Restuina. 2004. Tesis. "Kajian Pemanfaatan Ruang Pesisir Kota Ternate Provinsi Maluku Utara”. Universitas Diponegoro Semarang.Semarang.

Fitrul, Kamal. 2009. Skripsi. "Hubungan Antara Tingkat Pengetahuan Dan Sikap Ibu Ruma Tangga Tentang Pengelolaan Sampah Dengan Perilaku Pembuangan Sampah Pada Masyarakat Sekitar Sungai Beringi”. Universitas NegeriS emarang. Semarang.
Juli Soemirat. 2011 "Kesehatan Lingkungan" Yogyakarta. Gadja mada University Press

Lasman Rohani. 2007. Skripsi. "Perilaku Masyarakat Dalam Pengelolaan Sampah Di Desa Medan Dan Di Kelurahan Asam Kumbang" universitas Sumatera Utara. Medan.

La Sara. 2014 "Pengelolaan Wilayah Pesisir". Bandung. Alfabeta.

Lohani lasman. 2007. Skripsi. "Perilaku Masyarakat Dalam PengelolaanS ampah Di Desa Medan Senembah Kabupaten Deliserdang dan Di Kelurahan Asam Kumbang Kota Medan". Universitas Sumatera Utara. Medan.

Nazir Moh. 2014 "Metode Penelitian" Jakarta. Ghalia Indonesia.

Notoatmodjo Soekidjo. 2012 "Metodologi Penelitian Kesehatan”. Jakarta. Rineka Cipta.

Notoatmodjo Soekidjo. 2014 "Ilmu Perilaku Masyarakat”. Jakarta. Rineka Cipta.

SoekidjoNotoatmodjo. 2011"Kesehatan Masyarakat”. Jakarta. Rineka Cipta.

SumatriArif, 2013"Kesehatan Lingkungan". Jakarta, Kencana. 